\title{
Innovative Strategies for Small Retail Companies' Sustainability
}

\author{
Dr. Desire S. Luamba ${ }^{1}$, Dr. Marvin L. J. Blye ${ }^{2}$, Dr. Irene A. Williams ${ }^{3}$ and Joel Chagadama ${ }^{4}$ \\ ${ }^{1}$ Adjunct Faculty, Trevecca Nazarene University, Nashville, TN, USA \\ ${ }^{2}$ Deputy Chief Financial Officer, City of Baltimore-Department of Housing and Community Development, USA \\ ${ }^{3}$ Senior Contributing Faculty, College of Management and Technology, Minneapolis, Walden University, USA \\ ${ }^{4}$ Chief Financial Officer, Suburban Kitchen Company, Virginia, USA
}

*Correspondence: Dr. Desire S. Luamba, luambade@gmail.com

\begin{abstract}
Forty-one percent of small American retail companies fail to succeed beyond 5 years. The purpose of this multiple case study is to explore strategies small retail business owners need for sustainability beyond 5 years. This study's data were collected through face-to-face interviews with 4 small successful retail business owners located in the United States southeastern region. Based on the conceptual framework of Schumpeter's innovation theory, the paper provides 3 strategies that may prevent failure and lead to small business sustainability: passion and determination, market development and customer satisfaction, and business model innovation.
\end{abstract}

KEYWORDS: Innovative strategies, Business sustainability, small business owners

\section{ARTICLE INFORMATION}

Author(s): Dr. Desire S. Luamba, Dr. Marvin L. J. Blye, Dr. Irene A. Williams and Joel Chagadama

Received: 09 Aug, 2021; Accepted: 23 Aug, 2021; Published: 10 Sep, 2021 e-ISSN: 2347-4696;

Paper Id: BMN-IJBMR-2021-61;

Citation: doi.org/10.37391/IJBMR.090311

Webpage-link:

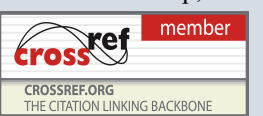

https://ijbmr.forexjournal.co.in/archive/volume-9/ijbmr-090311.html

\section{INTRODUCTION}

The economic development or growth of a country depends on its business activities. To develop business activities, the United States created the Small Business Administration (SBA) on July 30th, 1953, with the mission to assist financially and technically small businesses to become economically viable and sustainable over time [1]. However, despite the government's effort to promote small business activities, some business analysts have predicted that $50 \%$ of small new companies may collapse within their first 5 years for lack of effective business strategies [1]. As this study explores appropriate business strategies small retail business owners need for long-term sustainability and profitability, the authors collected data from the interview with real individuals who have experienced the phenomenon and who have had business experience for more than 5 years. Thus, this present paper will present recommendations that small business owners may need to sustain their business activities beyond their first 5 years and promote a positive social change in the local communities by improving the social and economic developments from income generated by new jobs.

\section{BACKGROUND}

Over recent years, the role of small company activities has become vital for both communities and governments [2, 3]. According to Haltiwanger, et al. [4], small business activities affect economic, social, and political development. For example, from January to May 2016, small companies have created 1.1 million jobs in the United States [1]. Since the 1970 s, small companies have provided at least $66 \%$ of new jobs. According to the government forecast, this number could increase in the next 10 years because of the rapid development of technology and the entrepreneurial spirit of new investors and entrepreneurs [1].

Then, helping small companies to reach success has become crucial for the government because of the economic and social benefits that arise from business activities. However, to remain competitive, small companies' owners need sustainable and durable strategies to succeed beyond their first five years [5]. Moreover, with the pressure of globalization, competition and business challenges have increased among small, medium, and large companies [6]. Small companies' owners or managers should have skills, knowledge, experience, passion, and business strategies to remain competitive in the market [7]. Some researchers have explained the causes and consequences of small companies collapsing, but this research focuses on implementing strategies to sustain small companies' longevity.

\section{INNOVATION THEORY}

The conceptual framework for this study is Schumpeter's innovation theory. Schumpeter's innovation theory attests that innovation is the primary factor of increasing growth in business activities [8]. Schumpeter also argued that innovation should be understood as a combination of new ideas or production processes that lead to the success or creation of new products. Per Schumpeter, the following fundamental concepts underline innovation theory (a) introduction of a new product, (b) development of a new method of production, (c) opening a new market, (d) developing new sources of replenishment, and (e) carrying out the new organization of the company [9]. Schumpeter also argued that a productive and progressive business must enjoy creating new things or ideas to make more profits and last for a long time. As applied to this study, Schumpeter's innovation theory holds crucial elements that contribute to analyze and explore strategies 
small retail company owners need to improve profitability and longevity beyond 5 years.

\section{METHODOLOGY}

\subsection{Population and Sampling}

The sample size of the population for this qualitative multiple case study is 4 small retail business owners located in the United States' southeastern region who have sustained and promoted their businesses beyond the first 5 years. The United States' southeastern region has at least 6,723,178 small business owners [12]. Participants were selected using the purposive sampling method. Sue, et al. [13] argued that the purposive sampling method is crucial to identify and select participants who experienced the phenomenon and who could provide rich and valuable information for the research study. Using the Google search engine and exploring SBA reports, the purposive sampling method helped us to select the four participants among other successful small retail business owners located in the same region. The purposive sampling also helped to select participants who met the eligibility criteria, which are: (a) be an owner or top manager of a small retail business in the southeastern region of the United States for more than 5 years, (b) employ no more than 500 employees, and (c) generate annual revenues between $\$ 500,000$ and $\$ 50$ million.

\subsection{Procedures}

The primary research question was: What strategies do small retail business owners need for sustainability beyond 5 years? And the seven interview questions were: (a) What strategies have you used to maintain your retail business for over 5 years? (b) What were the key barriers to implementing your successful strategies beyond 5 years? (c) How did you address the key barriers to implementing your strategies for more than 5 years? (d) What strategies have you used for targeting and retaining your customers? (e) How have you assessed the effectiveness of your strategies for more than 5 years? (f) What strategies have you used to remain competitive in the market? And (g) what else would you like to share about strategies to sustain your business for more than 5 years?

For the validity of data collection instruments, we referred to Jamshed's research [14]. Jamshed explored using open-ended questions by qualitative researchers to analyze and understand a phenomenon in-depth. All participants had the same interview questions and the same time of the interview (20 minutes). Participants were recorded during the interview processes and encouraged to ask questions to clarify and avoid misunderstandings. After the interviews, we used member checking to verify transcripts and ensured data interpretation and transcript reviews were accurate. Researchers use member checking for increasing accuracy, reliability, validity, and credibility of participants' responses [15-18]. As required by ethical norms, we used data coding symbols P1, P2, P3, and $\mathrm{P} 4$ for participants $1,2.3$, and 4 to protect participants' privacy and confidentiality. We also transcribed the data and used member checking to allow each participant to review his/her responses and confirm his/her declarations.

\subsection{Data Analysis}

After data collection using the face-to-face semi-structured interview questions and reviewing company documents and public information, we confirmed data saturation after interviewing the fourth participant and reported the data into NVivo 12. Data were coded, categorized, and labeled through the content analysis of this research, based on all information collected from open-ended interview questions. The analysis of codes and themes from NVivo 12 helped to find and understand effective strategies small retail business owners used to sustain their business longevity for more than 5 years. Saldana [19] stated that researchers need to emphasize the quality of data rather than the quantity because the quality positively affects the findings of the research. For the research and data quality, we used the concept of innovation as described by Schumpeter [9] to evaluate the impact of innovation on business sustainability.

Moreover, for the research consistency, accuracy, validity, and reliability, we used methodological triangulation. Researchers use methodological triangulation to provide a comprehensive view of the phenomenon when collecting data from multiple sources [20-22]. Cope [23] and Kirby, et al. [24] argued that methodological triangulation is useful for collecting data from various sources such as interviews, companies' internal documents, and governments' official documents. Yin [11] identified five steps in the data analysis process: (a) locating and defining problems, (b) designing the research project, (c) collecting data, (d) interpreting data, and (e) reporting the research analysis. Then, we collected, regrouped, interpreted, analyzed the data, and presented the conclusions of data analysis in the following section.

\section{RESULTS}

From NVivo 12, we identified themes, sub-themes, patterns, and trends that emerged from the data collection technique. The major themes that emerged from this study were (a) passion and determination of doing business, (b) market development and customers' satisfaction, and (c) business model innovation. Previous scholars noted that researchers must identify themes from data analysis and provide a code to each theme in the first stages of analysis by grounding and linking the data to the broader analytic context $[25,26]$. The results of data analysis indicated that participants used innovation as a strategic managerial tool to advertise on social media, analyze customers' behaviors, assess market trends, and sustain their companies' performances and longevities. All four participants agreed that innovation encompasses critical factors related to business management and leadership, which led to the development of new business strategies and contributed to increasing profits, sales, and customer satisfaction. Three out of four participants indicated that with the advances of technology and the Internet, innovation was strategic for organizing, planning, and monitoring business activities in real-time and at a low cost. Taneja, et al. [27] confirmed in their research that innovation was a primary factor that led to increasing a company's visibility, profitability, and longevity. Participants also agreed that innovation led to the sustainability of their business even 
during the low seasons. For instance, during low seasons, when there is such as snow, rain, storm, or other natural disasters, their businesses were open as usual. During those particular situations, their strategy to increase sales was to sell online and ensure home deliveries. Boglan [28] echoed that seasonal conditions may affect negatively sales, and managers need innovative strategies to analyze market development and develop innovative ideas like telemarketing and home delivery to maintain sales and promote customers' satisfaction.

P2 and P3 argued that using innovation strategy in compliance with business regulations and laws prevented them from some harmful acts such as mismanagement or penalization. P2 and P3 attested that their strategy to use accounting software like QuickBooks prevented them from penalization and contributed to declare and pay taxes on time without additional costs. Moreover, Gordian and Evers [29] stated that complying with business regulations is strategic to prevent fraud, promote business growth, and avoid tax penalization. P2 and P3 added that managers who understand the impact of business compliance have the chance to succeed and prevent business failure. P2 and P3 also stated that companies that lack appropriate technological tools might have difficulties overseeing business activities, preventing fraud, and controlling financial resources in real time. In support of participants' statements and experience, Beena and Paul [30] suggested that adopting an innovative business approach is crucial for managers to understand and apply commercial laws and regulations. Mastering business laws and policies are crucial to promote and sustain business activities.

As stated above, small retail business owners used innovation to explore and share their market information and experience. For the security and protection of their businesses, small retail business owners used their innovative ideas to remain competitive and secure their business against the competition of middle and large companies that sold the same products or services. Middle and large companies' effects on small business activities may be devastative because middle and large organizations always have enough financial and technical resources to advertise and compete efficiently. Moreover, cooperation and collaboration among business managers are paramount to promote a win-win strategy, encourage transparency and awareness, and lead to successful business practices [31]. Three participants reported that cooperation was crucial to create a commercial relationship between them and sustain business growth. P2 and P4 also used the membership agreements of their mutual organizations to get daily and weekly updates on business information about new regulations and products. Besides using innovation to promote cooperation among members or between members, all participants agreed that their strategy to use business model innovation helped secure their assets and create new resources to remain competitive over time. To sum up, all participants indicated that using innovation was crucial to promote the passion and determination for doing business, market development and customer satisfaction, and business model innovation strategies to sustain profitability and longevity for more than 5 years.

\author{
Emerging Theme 1: The Passion and Determination of \\ Doing Business:
}

Passion and determination to do business was the first emerging theme of this study. The sub-themes that emerged from passion and determination were (a) business experience and skills, (b) understanding business practices, (c) honesty and loyalty, and (d) management and leadership styles. Responses for passion and determination of doing business came from interview questions 1 and 2, which focused on business sustainability, leadership, and management styles. Cardon, et al. [32] argued that the passion of business comes from a variety of sources like competition, people or customers, products, services, and social missions. Similarly, Thibault-Landry, et al. [33] used the self-determination theory to examine the relationship between employees' work cognitions, psychological needs, and work intentions. In their analysis, the authors found that individuals' motivation and determination come from factors like competence, relatedness, and business autonomy.

Moreover, Thibault-Landry, et al. [33] expressed that passion and determination increase the chance to succeed and meet organizational goals. The data collected from interviews, financial and daily business reports indicated that all participants had the desire and determination to do business. $\mathrm{P} 1, \mathrm{P} 2$, and $\mathrm{P} 4$ mentioned in their response that passion and determination motivated them to work even during snow, rain, or holy days, which helped them increase customer satisfaction and business performance. All participants agreed that having business experience and skills, understanding business practices, being honest and loyal with customers, and possessing practical managerial and leadership styles promoted their passion and determination to do their business with success. Each of the participants revealed personal examples of how their passion and determination contributed to success and longevity. For example, P1 declared, "Most of the time, I always try to listen to my customers because I am passionate, charismatic, honest and loyal, and have experience and determination to lead effectively and promote my business longevity together with clients." P2 echoed, "My permanent love of doing business and my desire to be successful helped me to sustain my business during the low and high seasons, which allowed me and my business to be competitive and successful for a long time." P3 declared that "Because of my passion and determination, I was able to run my business well, and realized that my efforts contributed to be successful for many years and hope even forever." P4 added, "My passion, determination, and business experience come from my education as a master's of business management, experience, and observation of other successful and famous businessmen around me who managed their companies for many decades." P1, P2, and P4 added that active managerial and leadership skills were also important factors that contributed to reaching our companies' goals and missions. Some authors and researchers argued that effective business managers should be innovators, experienced, and passionate to sustain their business longevity [34]. All participants confirmed that their motivation and determination in managing their business 
activities associated with their business experience, skills, and practices were crucial to promote customers' loyalty. Moreover, all participants added that management and leadership styles were also the significant factors that led to business sustainability and longevity (Table 1). The findings supported Thibault-Landry, et al.'s [33] statement, which argued that managers should focus on their passion and determination to sustain productivity and longevity.

\section{Business Experience and Skills}

Participants revealed that business experience was another factor that sustains small business activities (Table 1). P2 and P3 noted that having business experience and skills is essential to promote business activities. P2 and P3's statements aligned with the findings of Mohsin, et al. [35]. Mohsin, et al. [35] asserted that business managers need business experiences, skills, and strategies to increase profitability and sustain productivity. P4 stated that his strategy to hire experienced and skilled employees contributed to maintaining a high standard of business practices. Then, Bishop [36] stated that using skilled and talented employees is critical to meet and increase customers' demands.

\section{Understanding Business Practices}

Balfanz and Verran [37] defined business practices as operational activities that promote success within a business. P3 and P4 stated that understanding business practices is strategic to reach a company's goal. Moreover, because of budget constraints, P3 and P4 used the strategy of learning by training and teaching their employees about understanding customers' behaviors and attitudes in the shop and on the phone. This strategy aligned with the analysis of Silvia [31], who stated that understanding business practices is critical to adopt new ideas and behaviors that could contribute to improving new products and services.

\section{Honesty and Loyalty}

To increase sales and ensure long-term productivity, managers should be loyal and honest with their customers [38]. Honesty and loyalty increase trust between managers and employees and between the company's employees and customers [39]. P1 and P2 noted that their experience of organizing professional training of all employees focused on product presentation and customers' retention and satisfaction were productive for promoting honesty and loyalty in their organizations. Moreover, P4 stated the experience of using necessary training to advise customers on some health issues from certain products contributed to building trust with customers and employees.

\section{Management and Leadership Styles}

The findings from the interviews indicated that appropriate management and leadership styles are essential for business viability. Making the right decision at the right moment and guiding employees to reach an organization's goal are qualities that real managers need for success $[40,41]$. P2 and P3 noted that their management and leadership styles enabled their employees to understand their mission and goals. For example, P3 added that the decision made after agreement with all employees about using a diversification strategy to invest in new products for Thanksgivings events enabled the company to sell more products than usual. This statement supported the existing literature of Benson [42] who stated that business owners must have aptitudes and qualities to get their team involved in their vision for success.

\begin{tabular}{|l|l|l|}
\hline Nodes/Themes & $\begin{array}{l}\text { Number of } \\
\text { participants }\end{array}$ & $\begin{array}{l}\text { \% of participant } \\
\text { agreement with } \\
\text { sub-themes }\end{array}$ \\
\hline $\begin{array}{l}\text { Business experience } \\
\text { and skills }\end{array}$ & 4 & 100 \\
\hline $\begin{array}{l}\text { Understanding } \\
\text { business practices }\end{array}$ & 4 & 100 \\
\hline Honesty and loyalty & 3 & 75 \\
\hline $\begin{array}{l}\text { Management and } \\
\text { leadership styles }\end{array}$ & 3 & 75 \\
\hline
\end{tabular}

Table 1: Passion and determination of doing business.

\section{Emerging Theme 2: Market Development and Customers' Satisfaction:}

The second emerging theme was market development and customer satisfaction.

Market development and customers' satisfaction sub-themes were (a) customers' attitudes and behaviors, (b) product quality, (c) customer service, and (d) price strategy. Tchamyou [43] analyzed the role of knowledge of economy in business. The author found that education, innovation, and information were critical for market development through new products or services to increase customers' satisfaction and explore new opportunities that managers need to increase business development. Market development and customer satisfaction allow managers to ensure success [44]. The themes of market development and customers' satisfaction emerged from questions $1,3,4$, and 6 , in which the authors explored the connection of participants to business sustainability, customers' satisfaction, retention, and market competitiveness. The theme of market development and customers' satisfaction aligned with the innovation theory because participants used market development analysis when analyzing the market evolution and understand customers' behaviors regarding new products or prices to retain and attract customers. Christensen [45] stated that business innovation is critical for creating new market values and customer retention. After analyzing companies' seasonal trends and monthly inventory reports, it became clear that managers wanted to avoid shortages and satisfy customer demand. All participants agreed that analyzing market trends and improving customers' satisfaction was strategic to increase sales and profits. Participants also acknowledged that analyzing customers' attitudes and behaviors, enhancing product quality, improving customer service, and establishing a competitive price strategy was among the elements of market development and customer satisfaction that contributed to their business development (Table 2). 
Moreover, participants agreed that market development and customer satisfaction allowed them to predict sales during the high season and special event days like the first day of the year, Christmas, Easter, July 4, and Halloween. Madura [38] revealed that understanding the business environment and market research helps to be competitive and increase customer satisfaction. Participants agreed that customer satisfaction led to market development and business expansion. P2 stated, "To maintain my business over 5 years, I used my business skills and experience to identify my real customers and give them what they needed and where they wanted it". P3 added, "I always try to improve customer service by offering excellent services and good product quality." P4 indicated, "We buy our products to satisfy our customers' demands and to avoid shortages. We focus on market development to learn customers' attitudes and identify new products that match with customers' demands." P1, P2, and P4 also added that price strategy was a critical factor to attract and retain customers.

Some researchers encourage business managers to be talented and ambitious in increasing customers' satisfaction to increase sales and profits [46]. Participants used innovation as a strategy to gather data from surveys and phone calls to learn customers' behaviors and improve the products and service quality to promote customer service. Three participants suggested prioritizing the roles and needs of customers and communicating effectively with them when presenting new products to increase their desire to buy. The findings were substantial with Tchamyou's [43] analysis relative to promoting customers' positive attitudes, products' quality, customers' service, and price strategy for increasing sales and customers' satisfaction for long-term productivity.

\section{Customers' Attitudes and Behaviors}

Managers who want to succeed should use innovation strategy to identify loyal customers and analyze their attitudes and behaviors when purchasing their products to increase trust between the organization and customers [47]. The interviews' findings indicated that participants analyzed customers' behaviors to understand their attitudes toward new products (Table 2). P4 and P2 reported that analyzing customers' attitudes, and behaviors enabled their companies to order and sell products that met customers' needs. This strategy allowed their companies to increase sales and profits.

\section{Products Quality}

Customers usually need to buy good quality products that meet their desires [38]. Gordian and Evers [29] unveiled that managers who promote products' quality increase their chance to meet customers' demands and reach success. P1, P2, and P4 focused on selling the best quality of products to increase sales. P1, P2, and P4 also noted that ensuring a good quality of products enabled their companies to preserve a good reputation.

\section{Customer Service}

Kandampully [48] defined customer service as a position in a business structure that ensures a good quality of service before, during, and after selling. The findings from interviews indicated that participants promoted customer service to increase and retain customers (Table 2). P1 revealed that excellent customer service promotion enabled the company to get enough information about regular and potential customers. P1 added that customer service is paramount to help and motivate buyers to purchase more products. P3 echoed that customer service is about how the company treats and considers customers in business.

\section{Price Strategy}

Kireyev, et al. [49] noted that price is one of the critical factors that motivate customers to purchase products. P2, P3, and P4 used price strategies for increasing competitiveness. For example, P3 applied the .99 pricing strategy to small items. P4 added that the use of the slogan "buy one and get the second at half price" enabled the company to increase sales. Participants agreed that price strategy was strategical to target defined customers and competitors to increase sales.

\begin{tabular}{|l|l|l|}
\hline Nodes/Themes & $\begin{array}{l}\text { Number of } \\
\text { participants }\end{array}$ & $\begin{array}{l}\text { \% of participant } \\
\text { agreement with } \\
\text { sub-themes }\end{array}$ \\
\hline $\begin{array}{l}\text { Customers' attitudes } \\
\text { and behaviors }\end{array}$ & 4 & 100 \\
\hline Products quality & 3 & 75 \\
\hline Customer's service & 4 & 100 \\
\hline Price strategy & 3 & 75 \\
\hline
\end{tabular}

Table 2: Market development and customers' satisfaction.

\section{Emerging Theme 3: Business Model Innovation:}

The emerging theme of business model innovation comes from questions 2, 3, 5, and 7. The sub-themes that emerged from the theme business model innovation were (a) adaptation to change, (b) marketing plan, and (c) technology innovation. The participants recommended using compelling innovative strategies such as digital marketing campaigns on social media to post signs, pictures, and videos to improve business practices. Donate, and Pablo [50] explored the relationships between knowledge management practices, organizational leadership, and innovation. Using the partial least squares (PLS) statistical technique in a sample of technology firms in Spain, the author found that knowledge of management practices impacts a firm's model innovation performance and leads to development and longevity. Poorkavoos, et al. [51] concluded in their analysis regarding innovation requirements and found many paths to reach innovation. The authors argued that managers need to assess organizations' internal capabilities before engaging in innovation processes. Christensen, et al. [52] echoed that business model innovation leads to increasing an organization's resources by promoting products and services offered to customers. All participants' responses indicated that small business owners used the concept of innovation theory in business model innovation to attract, retain, and satisfy their customers to maintain their business in the market. P2, P3, and P4 argued that business 
model innovation was essential to compete effectively and attract new customers because of market challenges to reach new customers in the evolving and open market. P2 and P3 presented their business model innovation plans for 2015 and 2016 in which they described the acquisition of new scanners for inventory, monitoring cameras, and automated text messages and emails.

After analyzing interview data, marketing plans, business model plans, and a list of loyal customers, it became clear that managers need creativity and innovation to sustain businesses. The findings also showed that during the low seasons of sales, each participant applied the business model innovation strategy to increase profits and sales. P1 and P2 warned that sustainability and adoption of the market changes were sometimes challenging to reach. Still, business model innovation helped them double their profits, remain sustainable, and adopt market changes innovatively. P3 recommended that business leaders should use a business model innovation strategy that corresponds to the company's mission to explore new opportunities that offer the market to remain competitive. P3 also stated that innovation and business model innovation brought new ideas in leading, managing, overseeing, and controlling daily business operations.

Moreover, participants confirmed that using innovation strategy associated with adaptation to change, marketing plan, and technology innovation strategies was among the strategic factors that promoted a sustainable competitive advantage of their businesses and implemented additional profits for many years (Table 3). Similarly, Makhmoor and Rajesh [53] attested in their findings that the use of business model innovation had the chance to increase profits four times more than a classic business model. P1 stated, "In today's business environment, with the development of innovative technology, we can have managerial information in real-time, identify in advance any potential issues in the production processes, and find solutions before it affects sales or stocks." P3 echoed, "With the advance of technology innovation, we can sell online and reduce the company's production costs and increase profits." P4 argued, "Using innovation strategy helps to advertise at a low cost by using free socio-media such as Facebook, Twitter, and Text message to maintain sales." Three out of four participants suggested that small retail business leaders should adopt changes, implement marketing plans, and use technological innovation for an efficient business model innovation to increase sales and sustain long-term longevity. The findings were consistent with the requirement to use business model innovation as a strategic business tool for business growth and expansion for more than 5 years.

\section{Adaptation to Change}

In the current business context, managers need to accept and adopt the change to remain competitive because of the rapid evolution of technology and new regulations [54, 55]. Xu, et al. [56] indicated that managers need to adopt change because the world evolves with the increasing number of people, businesses, and regulations. P1, P3, and P4 noted that adopting changes in dealing with customers, suppliers, and government leaders positively impacted their business growth. P3 expressed that changing business location and hiring local employees enabled the company to increase its customers. Moreover, P3 added that changing the strategy to hire locally had a positive impact because local employees may have friends, colleagues, or family members who are potential customers for the business.

\section{Marketing Plan}

Madura [38] defined a marketing plan as a list of business actions related to advertising and marketing projects for the coming year. P1, P2, and P4 used marketing plans to target customers who may buy their products now or in the future. P1, P2, and P4 noted that they planned in their marketing plans to use social media like Facebook, Twitter, WhatsApp, Linked In, Newspapers, TV, and instant text messages to advertise and interact with customers. P2 indicated that using instant text messages was productive to target customers at any time.

\section{Technology Innovation}

With technological advances, managers can work, monitor business activities, and make effective decisions using technological assistance tools [57, 58]. Bercu, et al. [59] argued that technology innovation allows managers to have inventories, sales, production costs and assess business activities in real-time and at a low cost. The findings from interviews aligned with Bercu, et al.'s [59] findings and indicated that participants used technology innovation to reduce production costs and increase profits (Table 3). P2 also noted that technology innovations like surveillance cameras and barcode scanners enabled the company to reduce losses and present a reliable inventory.

\begin{tabular}{|l|l|l|}
\hline Nodes/Themes & $\begin{array}{l}\text { Number of } \\
\text { Participants }\end{array}$ & $\begin{array}{l}\text { \% of participant } \\
\text { agreement with sub- } \\
\text { themes }\end{array}$ \\
\hline Adaptation to change & 3 & 75 \\
\hline Marketing plan & 3 & 75 \\
\hline $\begin{array}{l}\text { Technology } \\
\text { innovation }\end{array}$ & 4 & 100 \\
\hline
\end{tabular}

Table 3: Business model innovation.

The results of this qualitative multiple case study revealed that using (a) passion and determination of doing business, (b) market development and customers' satisfaction, and (c) business model innovation was critical strategies that sustained small retail business activities more than 5 years. Small business owners who are struggling to compete and remain active in the market should explore the advantages of innovation theory and this study's findings to sustain their activities for more than 5 years. Business owners may have different strategies to sustain their activities; however, finding appropriate and innovative business strategies is critical for sustaining business longevity. Moreover, all participants indicated that aligning innovation with passion and determination, market development and customer satisfaction, 
and business model innovation was strategic for small retail business owners to remain sustainable in the market for more than 5 years.

\section{CONCLUSION}

Small retail businesses are job creators and promoters of social change and economic development. The success of small businesses is crucial for owners, managers, entrepreneurs, and government leaders. The impacts of globalization and technological advances on business activities have increased market competition, making it challenging for some small retail businesses to survive for more than 5 years. Small business owners and leaders need to look beyond invention and develop innovative strategies that reduce production costs, increase sales, and sustain longevity. This research aimed to explore business strategies small retail business owners use to remain sustainable beyond 5 years. Exploring innovation theory in business practices leads to ensure success and longevity for companies. Although, exploring innovative ideas contributes to preventing failure and enhancing the development of businesses for the long term.

In the current business context, innovation has become unavoidable for small retail business owners to maintain and sustain their business activities. Consequently, using Schumpeter's innovation theory, the results of this study indicated that when business owners adjust their strategies based on consumers' feedback, consumers' behaviors, and market trends, it helps develop successful innovative strategies. The authors confirmed that the model proposed by Schumpeter [9] not only provides strategies to analyze and assess organizational growth but offers a comprehensive view into change initiatives to develop and sustain any business activity. Small retail business owners should look at their business practices and develop procedures to ensure appropriate strategies and methods to sustain themselves beyond 5 years.

This study's findings revealed three effective strategies small retail business owners use for productivity, profitability, and sustainability of their businesses. The authors also confirmed that the three strategies focused on the: (a) use of passion and determination to succeed, (b) analysis of market development and customer satisfaction to increase sales, and (c) application of business model innovation to create new resources and increase a company's value were valuable for small business sustainability. Current retail business owners who are in a distressing situation, potential entrepreneurs, researchers, and government leaders can benefit from this study's findings to learn and understand the relationship between using innovation and implementing business strategies to develop sustainable plans for small business longevity. The findings may also contribute to promote a positive social change by increasing the employment rate and enhancing economic development.

\section{LIMITATIONS}

Marshall and Rossman [10] defined limitations as potential weaknesses based on obstructive conditions that can influence the research interpretations and findings. Yin [11] added that researchers need to be specific by limiting their studies to focus on the topic, otherwise the research would be too large with the risk of not meeting the objective of the study. The limitations of this research included (a) the use of only one theory of innovation, (b) the focus on only the retail industry, and (c) the focus on only small retail business owners as participants.

\section{REFERENCES}

[1] Small Business Administration (SBA). (2016). Advocacy: The voice of small business in government.

[2] Junaidu, A., Abdul, M., Mohamed, Z., \& Sambasivan, M. (2012). Tangible resources and export performance of SMEs in the Nigerian leather industry: The moderating role of firm size. International Journal of Academy Research in Economics and Management Sciences, 1, 235-247.

[3] Taranenco, H. L. (2013). Concept of sustainable development of small and medium enterprises in Moldova. Knowledge Horizons. Economics, 5, 126-129.

[4] Haltiwanger, J., Jarmin, R.S., \& Miranda, J. (2013). Who creates jobs? Small versus large versus young. Review of Economics and Statistics, 95, 347-361.

[5] U.S. Small Business Administration. (2016a). Frequently Asked Questions.

[6] Parmer, L., \& Dillard, J. (2015). The relationship between personality and consumer behavior buying patterns within the automobile industry. Global Conference on Business and Finance Proceedings, 10, 286-295.

[7] Bereznoi, B. (2014). Business model innovation in corporate competitive strategy. Problem of Economic Transition, 57(8), 13-33.

[8] Schumpeter, J. A. (1934). Theory of economic development: An inquiry into profits, capital, credit, interest, and the business cycle. Cambridge, MA: Harvard University Press.

[9] Schumpeter, J. A. (1935). The analysis of economic change. The Review of Economics and Statistics, 17(4), 2-10.

[10] Marshall, C. \& Rossman, G. (2016) Designing Qualitative Research. SAGE, Thousand Oaks.

[11] Yin, R. K. (2017). Case study research and applications: Design and methods (6th ed.). Thousand Oaks, CA: Sage.

[12] Office of Small Business Advocate. (OSBA). (2016). Tennessee comptroller of the treasury.

[13] Suen, L. W., Huang, H., \& Lee, H. (2014). A comparison of convenience sampling and purposive sampling. Huli Zazhi, 61, 105-111.

[14] Jamshed, S. (2014). Qualitative research method-interviewing and observation. Journal of Basic and Clinical Pharmacy, 5(4), 87-88.

[15] Birt, L., Scott, S., Cavers, D., Campbell, C., \& Walter, F. (2016). Member checking: A tool to enhance trustworthiness or merely a nod to validation? Qualitative Health Research, 26, 1802-1811.

[16] Carroll, W., \& Huxtable, D. (2014). Expose, oppose, propose: The Canadian center for policy alternatives and the challenge of alternative knowledge. Labour / Le Travail, 74(1), 27-50. 
[17] Varpio, L., Ajjawi, R., Monrouxe, L. V., O'Brien, B. C., \& Rees, C. E. (2017). Shedding the cobra effect: Problematizing thematic emergence, triangulation, saturation, and member checking. Medical Education, 51(1), 40-50.

[18] Zitomer, M.R., \& Goodwin, D. (2014). Gauging the quality of qualitative research in adapted physical activity. Adapted Physical Activity Quarterly, 31, 193-218.

[19] Saldana, J. (2016). The coding manual for qualitative researchers (3rd ed.). Thousand Oaks, CA: Sage Publications, Inc.

[20] Bekhet, A. K., \& Zauszniewski, J. A. (2012). Methodological triangulation: An approach to understanding data. Nurse Researcher, 20(2), 40-43.

[21] Morse, J.M. (2015). Critical analysis of strategies for determining rigor in qualitative inquiry. Qualitative Health Research, 25, 1212-1222.

[22] Patton, M. Q. (2015). Qualitative research \& evaluation methods: Integrating theory and practice (4th ed.). Thousand Oaks, CA: Sage.

[23] Cope, D. G. (2014). Methods and meanings: Credibility and trustworthiness of qualitative research. Oncology Nursing Forum, 41(1), 89-91.

[24] Kirby, E. R., Broom, A. F., Adams, J., Sibbritt, D. W., \& Refshauge, K. M. (2014). BMC Health Services Research, 14(131), 1-10.

[25] Nelson, J. (2017). Using conceptual depth criteria: Addressing the challenge of reaching saturation in qualitative research. Qualitative Research, 17, 554-570.

[26] Percy, W. H., Kostere, K., \& Kostere, S. (2015). Generic qualitative research in psychology. The Qualitative Report, 20(2), 76-85.

[27] Taneja, S., Pryor, M. G., \& Hayek, M. (2016). Leaping innovation barriers to small business longevity. Journal of Business Strategy, 37(3), 44-51.

[28] Boglan, R. (2016). The impact of innovation on the business model: Exploratory analysis of a small travel agency. ProcediaSocial Behavioral Sciences, 7, 166-175.

[29] Gordian, M., \& Evers, J. (2017). Reducing the risk of noncompliance. Pharmaceutical Executive, 37(2), 30-31.

[30] Beena S. S., \& Paul, E. (2016). Social innovation model for business performance and innovation. International Journal of Productivity and Performance Management, 65, 256-274.

[31] Silvia, M. (2015). Economic globalization: From microeconomic foundation to national determinants. Procedia Economics and Finance, 27, 731-735.

[32] Cardon, M. S., Glauser, M., \& Murnieks, C. Y. (2017). Passion for what? Expanding the domains of Entrepreneurial Passion. Journal of Business Venturing Insights, 8(1), 24-32.

[33] Thibault-Landry, A., Egan, R., Crevier-Braud, L., Manganelli, L., \& Forest, J. (2018). An empirical investigation of the employee work passion appraisal model using self-determination theory. Advances in Development Human Resources, 20, 148168.

[34] Hsu, D. K., Wiklund, J., \& Cotton, R. D. (2017). Success, failure, and entrepreneurial reentry: An experimental assessment of the veracity of self-efficacity and prospect theory. Entrepreneurship Theory and Practice, 41(1), 19-47.

[35] Mohsin, A. M. B. A., Halim, H. A., Ahmad, N. H., \& Farhana, N. (2017). Assessing the role of entrepreneurial competencies on innovation performance: A Partial Least Squares (PLS) approach. Journal of Business Inquiry. Research, Education \& Application, 16(1), 88-101.

[36] Bishop, D. (2015). Small firms and the failure of national skills policies: Adopting an institutional perspective. International Journal of Training and Development, 19(1), 69-80.

[37] Balfanz, H., \& Verran, B. (2015). Alma Chrysler jeep dodge ram: Home of buddy, the four-legged greeter. Journal of Business Case Studies (Online), 11(1), 35.

[38] Madura, J. (2015). International financial management (12th ed.). Stamford, CT: Cengage Learning.

[39] Hui, L., Chih-Wen, W., \& Yi-Han, C. (2015). The empirical study of consumers' loyalty for display technology. Journal of Business Research, 68, 2260-2265.

[40] Martin, A., Woods, M., \& Dawkins, S. (2015). Managing employees with mental health issues: Identification of conceptual and procedural knowledge for development within management education curricula. Academy of Management Learning and Education, 14(1), 50-68.

[41] Nelissen, J., Forrier, A., \& Verbruggen, M. (2017). Employee development and voluntary turnover: Testing the employability paradox. Human Resource Management Journal, 27, 152-168.

[42] Benson, D. (2015). The five fundamental tasks of a transformational leader. Physician Leadership Journal, 2(5), 5862.

[43] Tchamyou, V. S. (2017). The role of knowledge economy in African business. Journal of the Knowledge Economy, 8, 11891228.

[44] Jing, L., \& Su, J. (2014). Market orientation, technology orientation, and product innovation success: Insights From CoPS. International Journal of Innovation Management, 18(4), 1-25.

[45] Christensen, C. M. (1997). The innovator's dilemma: When new technologies cause great firms to fail. Boston, MA: Harvard Business Press.

[46] Glielnik, M. M., Spitzmuler, M., Schmitt, A., Klemann, D. K., \& Frese, M. (2015). I put in effort; therefore, I am passionate: Investigating the path from effort to passion in entrepreneurship. Academy of Management Journal, 58, 1012-1031.

[47] Subramanian, N., Gunasekaran, A., \& Gao, Y. (2016). Innovative service satisfaction and customer promotion behavior in the Chinese budget hotel: An empirical study. International Journal of Production Economics, 171, 201-210.

[48] Kandampully, J. (1998). Service quality to service loyalty: A relationship which goes beyond customer services. Total Quality Management, 9, 431-443.

[49] Kireyev, P., Kumar, V., \& Ofek, E. (2017). Match your own price? Self-matching as a retailer's multichannel pricing strategy. Marketing Science, 36, 908-930.

[50] Donate, M. J., \& de Pablo, J. D. S. (2015). The role of knowledge-oriented leadership in knowledge management practices and innovation. Journal of Business Research, 68, 360370.

[51] Poorkavoos, M., Duan, Y., Edwards, J. S., \& Ramanathan, R. (2016). Identifying the configurational paths to innovation in SMEs: A fuzzy-set qualitative comparative analysis. Journal of Business Research, 69(12), 5843-5854. 
[52] Christensen, C. M., Bartman, T., \& Van Bever, D. (2016). The hard truth about model innovation. MIT Sloan Management Review, 58(1), 31-40.

[53] Makhmoor, B., \& Rajesh, V. (2017). Why business model innovation is the new competitive advantage. IUP Journal of Business, 14(1), 7-17.

[54] Garba, A. S. (2017). Promoting entrepreneurship amidst poverty and unemployment: The role of Nigerian educational policies. International Journal of Asian Social Science, 7, 684-695.

[55] Velu, C. (2015). Business model innovation and third-party alliance on the survival of new firms. Technovation, 35(1), 1-11.

[56] Xu, K., Tihanyi, L., \& Hitt, M. A. (2017). Firm resources, governmental power, and privatization. Journal of Management, 43, 998-1024.
[57] Caldwell, B. (2015). Beyond positivism. (3rd ed.). New York, US: Routledge.

[58] Isal, Y., Pikarti, G., Hidayanto, A., \& Putra, E. (2016). Analysis of IT infrastructure flexibility impacts on IT-business strategic alignment. Journal of Industrial Engineering and Management, 9, 657-683.

[59] Bercu, A., Tofan, M., \& Cigu, E. (2015). New challenges concerning sustainable local development: Romance Case. Procedia Economics and Finance, 20(1), 65-71.

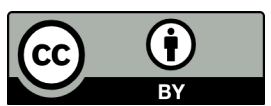

(C) 2021 by the Dr. Desire S. Luamba, Dr. Marvin L. J. Blye, Dr. Irene A. Williams and Joel Chagadama. Submitted for possible open access publication under the terms and conditions of the Creative Commons Attribution (CC $\quad B Y)$ license (http://creativecommons.org/licenses/by/4.0/). 